\section{Forbud mot tilskyndelse til selvdrap: en kommentar}

\author{
Ved Jon Bing
}

Etter norsk rett er det straffbart å medvirke til at noen tar sitt eget liv, jfr straffeloven $\S 236$. Bestemmelsen er utformet som et forbud mot "medvirkning". Dette uttrykket er en del av hverdagsspråket. Men i strafferetten er det på grunnlag av rettspraksis og juridisk litteratur bygget opp en lære rundt begrepet. Læren tar sikte på å skille mellom en straffri handling, som nok inngår i en kausalkjede frem til den straffbare handling, og en handling som er straffbar fordi den er å anse som "medvirkning".

Et enkelt og praktisk eksempel er at man f.eks selger en person et tau, som personen bruker for å ta sitt eget liv. Det er enkelt å forklare at selgeren ikke er straffskyldig, selv om tauet var et nødvendig element i et tragisk hendelsesforl $\varnothing \mathrm{p}$. Men hvis man endrer eksempelet til at en venn låner bort en pistol som så benyttes til selvdrap, skjønner man at dette etter omstendighetene lettere vil kunne vurderes som en kvalifisert bistand, og vil kunne anses som medvirkning.

Det finnes heldigvis ikke mange eksempler på dette i rettspraksis. Et eksempel er likevel en dom av Salten herredsrett (Rettens Gang 2001 s 741). Tiltalte fulgte en venninne som strevde med selvmordsplaner på en utenlandsreise som sluttet i Amsterdam. Det nærmere hendelsforløpet er noe uklart, men det trekkes ikke i tvil at tiltalte opptrådte som "livets likevel at "[d]et er naturlig å spørre hvorfor tiltalte ikke gjorde hva han maktet for å hindre gjennomføringen av selvmordet, for eksempel ved å kontakte personer i Norge eller hjelpeapparatet i de land hvor de befant seg. Eller i hvert fall ved å avstå fra å hjelpe henne.” virkning". ses i nasjonal rett. advokat" overfor venninnen. Retten sier

Retten viser til et forslag om å endre straffeloven for å unngå at "barmhjertighetsdrap" skal være straffbart. Imidlertid er situasjonen ved barmhjertighetsdrap ganske annerledes enn ved medvirkning til at en fysisk frisk person tar sitt eget liv. Om selve medvirkningen sier retten:

"Retten finner at tiltalte utvilsomt må sies å ha medvirket til at B tok sitt liv. Han kjøpte metadon og $\varnothing$ vrige ingredienser med det formål for $\varnothing y e$ at hun skulle bruke det til selvmordet ...

Retten vektlegger at tiltalte videre var sammen med B til hun sovnet, og at han oppholdt seg på rommet deler av natten. Han var der om morgenen, mens B ennå var i live. Når hotellbetjeningen banket på, sendte han dem bort. Så lenge B fortsatt pustet, kunne hennes liv antakelig fortsatt vært reddet, selv om faren for betydelig hjerneskade ... ville vært stor mot slutten."

I dette tilfellet er det elementer av både fysisk og psykisk medvirkning. En oppskrift offentliggjort på Internettet vil naturligvis ha en helt annen karakter. Det vil ikke være noen nødvendige bånd av vennskap eller personlig st $\varnothing$ tte som i den aktuelle saken, og det vil derfor være vanskelig å kvalifisere den som "med-

Man er varsom med å begrense ytringer, også ytringer av ubehagelig karakter, på grunn av det sterke vernet som ytringsfriheten har i norsk rett, jfr bl a Den europeiske menneskerettighetskonvensjon art 10 , som setter visse vilkår for at retten til å fremsette ytringer skal kunne begren-

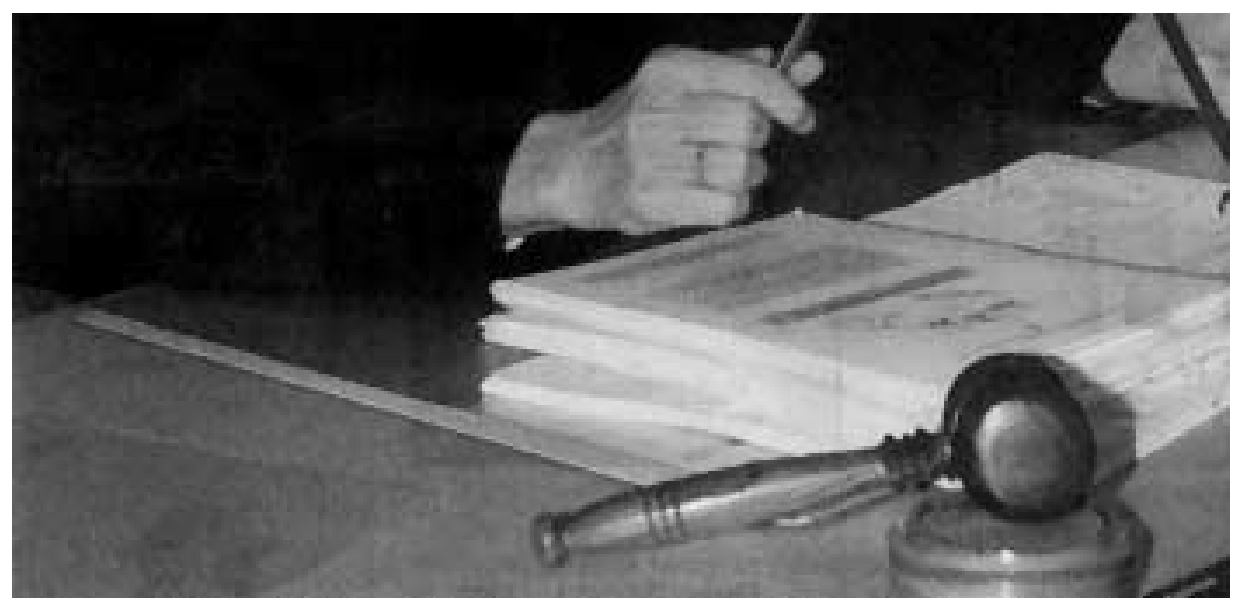

Dette

har ikke

forhindret

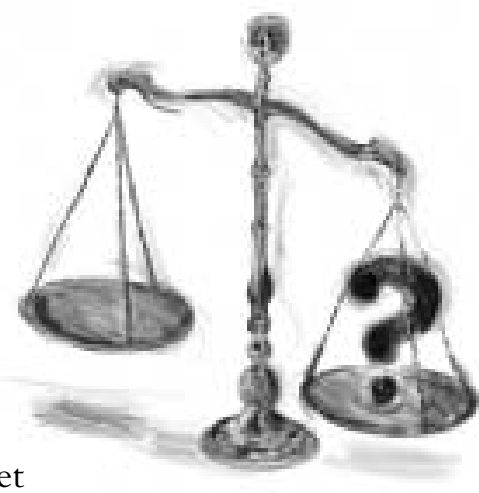

at straffeloven

$\S 149$ retter en straffetrussel mot den som "offentlig opfordrer eller tilskynder til Iværksettelsen af en strafbar Handling eller forherliger en saadan eller tilbyder at udføre eller bistaa ved Udførelsen af en saadan, eller som medvirker til Opfordringen, Tilskyndelsen, Forherligelsen eller Tilbudet".

Den som offentliggjør en oppfordring eller tilskyndelse til en straffbar handling på Internettet, vil klart kunne rammes av denne bestemmelsen helt uavhengig av hvorvidt man ser på tilskyndelsen som medvirkning til den straffbare handling som eventuelt blir resultatet av at noen følger oppfordringen eller oppskriften. Selve tilskyndelsen er en selvstendig, straffbar handling og straffebudet begrenser derfor ytringsfriheten. Dette er ikke problematisk i forhold til f.eks Grunnloven $\S 100$ eller EMK art 10.

Når en tilskyndelse til selvmord ikke rammes, kommer dette av det tekniske forhold at selvdrap ikke er straffbart. Det kan kanskje teoretisk virke litt paradoksalt at selvdrap ikke er straffbart mens medvirkningen rammes - men de bakenforliggende omstendigheter gir en så vidt lettfattelig forklaring at man ikke behøver å utdype begrunnelsen.

Imidlertid synes det nærliggende å anse at det på denne måten er oppstått et "hull" i lovgivningen. Åpenbart vil en kvalifisert oppfordring til selvdrap være like straffverdig som en oppfordring til vold mot politiet eller annen mer hverdagslig kriminalitet.

Det kan derfor virke nærliggende å foreslå en endring i straffeloven $\$ 149$ som likestiller oppfordring eller tilskyndelse til selvdrap med straffbare handlinger. Fremveksten av slike oppfordringer på Internettet, som er lett tilgjengelige fra enhver hjemmemaskin, kan nettopp være den aktualisering som kunne foranledige en slik lovendring.

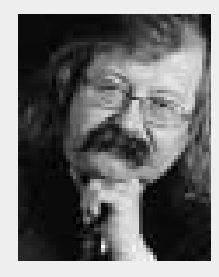

Jon Bing er

prof.dr.juris ved Institutt for rettsinformatikk, Det juridiske fakultet, Universitetet i Oslo. 